\title{
The Housing Development NGOs offering Housing Education and Training Programmes in South Africa
}

\author{
Winnie Lombard and Ria van Wyk
}

\section{OPSOMMING}

Die artikel beskryf nie-regeringsorganisasies wat behuisingsopleidingskursusse in Suid-Afrika aanbied. Dit argumenteer ook dat Verbruikerswetenskaplikes ' $\mathrm{n}$ rol in hierdie verband het om te speel.

Volhoubare behuisingsonwikkeling behels die fisiese lewering van huise, sowel as die ontwikkeling van die kapasiteit van gemeenskappe, die uitbreiding van geleenthede vir plaaslike ekonomiese ontwikkeling en die daarstelling of versterking van gemeenskapsorganisasies.

'n Twee-stap steekproefproses is gebruik om die relevante nie-regeringsorganisasies te identifiseer. Fokusonderhoude is as navorsingstegniek gebruik om ' $n$ kwalitatiewe beskrywende studie van die relevante nie-regeringsorganisasies te doen.

Slegs elf nie-regeringsorganisasies is in Suid-Afrika gevind wat gestruktureerde behuisingsopleiding verskaf as deel van hul behuisingsprojekte. Hierdie organisasies is ongelyk versprei in die verskillende provinsies van Suid-Afrika en is meestal slegs in stedelike gebiede werksaam.

Al elf die nie-regeringsorganisasies bied behuisingsopleiding sowel as gemeenskapsorganisasieontwikkelingsprogramme vir gemeenskappe aan. Slegs vier van die organisasies bied behuisingsopleiding vir gemeenskapsbehuisingsadviseurs aan, wat weer geleenthede vir plaaslike ekonomiese ontwikkeling aan die gemeenskap bied. Om te verseker dat behuisingsontwikkeling in gemeenskappe volhoubaar is, behoort meer geleenthede vir plaaslike ekonomiese ontwikkeling by projekte ingesluit te word.

\section{- Ms W Lombard}

Department of Consumer Science

University of Stellenbosch

\section{- Prof AS van Wyk}

Department of Consumer Science

University of Stellenbosch

* This article is based on a section of a Master's thesis that forms part of a research programme on multidisciplinary non-formal and formal housing education and training in South Africa, and was funded by the Foundation for Research Development.

\section{PURPOSE OF THE RESEARCH}

The research reported here forms part of a Housing Education and Training Research Programme that was funded by the National Research Foundation (NRF). The general aims of the research programme were to establish the need for housing education and training in South Africa on all levels of non-formal and formal education, to study the housing education and training initiatives currently offered in South Africa on all these levels, and to then develop a multidisciplinary strategy for housing education and training in South Africa. Needs assessments were done to determine the housing education and training needs of all the relevant role-players in the housing development field. The housing education and training initiatives that are currently offered in South Africa were also determined and evaluated in terms of the results of the needs assessments. From this information a framework and strategy for non-formal and formal housing education and training in South Africa has been developed.

The research, from which this article evolved, focused specifically on the non-government sector in South Africa. The research determined the status of NGOs that facilitate housing development and empowers communities through housing education and training. The macro (purpose, mission, goals and functions), intermediary (housing development programmes, relationships and problems) and micro systems (management systems, organisational processes and problems) of the NGOs were explored in terms of the four pillars of housing development identified by the research. Recommendations for the future support, education and training of these NGOs were made.

\section{PURPOSE OF THE ARTICLE}

The purpose of this article is to describe the status of the housing development NGOs that provide housing education and training courses as part of their housing development projects in South Africa. The article furthermore aims to encourage Consumer Scientists and the NGO-sector to form working relationships in the field of housing education and training.

\section{INTRODUCTION}

Housing as a process represents more than the delivery of houses (South Africa. Department of Housing, 1994:20). Housing is defined as "... a variety of processes through which habitable, stable and sustainable public and private residential environments are cre- 
ated for viable households and communities. This recognises that the environment in which a house is situated is as important as the house itself in satisfying the needs and requirements of the occupants" (South Africa. Department of Housing, 1994:21). Housing is further described in the Housing Act, 1997 (Act 107 of 1997) as both a product and process that is vital to the socio-economic well-being of a nation and which is a product of human endeavour and enterprise, as well as a function of the development process (South Africa. Department of Housing, 1997a:4).

Housing development as described in the Housing Act, 1997 (Act 107 of 1997) means the "... establishment and maintenance of habitable, stable and sustainable public and private residential environments to ensure viable households and communities in areas allowing convenient access to economic opportunities, and to health, educational and social amenities in which all citizens and permanent residents of the Republic will, on a progressive basis, have access to -

a) permanent residential structures with secure tenure, ensuring privacy and providing adequate protection against the elements; and

b) potable water, adequate sanitary facilities and domestic energy supply" (South Africa. Department of Housing, 1997a:4)

This definition of 'housing development', when integrated with the definition of 'housing' as described above, defines housing development as the establishment of a physical product, as well as a process of development that should lead to sustainable and stable environments with all that it entails. The process of development is dependent on different dimensions in order to make it sustainable over the long-term.

Fowler (1994:26) describes the process of development as "... an appropriate interweaving of three dimensions: improvement in physical well-being; local organisational strengthening; and community empowerment". Cernea (1992:40) adds to this "... even the most dynamic individuals are limited in their effectiveness if they are scattered and isolated, and if their efforts are not reinforced through group structures and group action". Jeppe (1985:29) accentuates this idea by saying that "...institutions with durability, autonomy, flexibility and homogeneity must be established or activated through which the needs and dynamism of the community can be implemented in an organised manner". One of the most important conditions for sustainability is institutional capacity building (Franks, 1996; Mikkelson, 1994:166). When the capacities of local institutions are not built through housing development projects, the result is an inability to sustain the gains of the housing development project in the longterm. To ensure a long-term effect, housing projects should be organised to strengthen local institutions (Gow \& Morss, 1988). These institutions need to acquire administrative and management capacity so that they can continue their functions after the support from the NGOs has been terminated or reduced (Mikkelson, 1994:183). The development process should also be backed up by opportunities for local economic development to enable communities to gain access to the necessary resources needed for development (Boeren, 1992; Jeppe, 1985:35; Meyer et al, 1995:271).

\section{Sustainable housing development}

With reference to the conclusions reached by the above-mentioned authors, the researchers identified four pillars that are necessary for sustainable housing development.

- The first pillar of housing development identified is the establishment of permanent physical residential structures with secure tenure and all the other physical elements as set out in the Housing Act, 1997 (Act 107 of 1997).

- The second pillar of housing development identified is the building of the capacity of the participating community at all levels (socially, mentally and technically) to such a level that they are empowered to participate in their own development.

- The third pillar identified to make communities sustainable through the housing development process, is the establishment or strengthening of local community institutions or organisations to such a level that they can maintain developments as well as orchestrate and conduct future developments within the community.

- For the community to become economically selfsustaining, opportunities need to be created where the community can utilise their inherent and newly developed capacity for local economic development. This then is the fourth pillar that was identified as necessary to make housing development sustainable.

Communities should be enabled to become economically empowered and independent from the State's financial assistance and to partake in the realisation of their own housing needs and the transfer of skills (South Africa. Department of Housing, 1994:23; Harding, 1994:13; Jeppe, 1992:68). The overall and ultimate aim should be to improve the quality of life of the community. This can only be reached through the participation of the people themselves in the process of housing development (Jeppe, 1985:27).

The process, and to a certain extent the finance, for providing housing in South Africa is in place, but the housing development process is not yet fully-fledged (South Africa. Department of Housing, 1997b:5). One of the problems impeding the housing development process is the lack of capacity among communities. Many consumers have too high expectations of the level of housing that can be delivered (South Africa. Department of Housing, 1994:15). There is a lack of understanding and insight about the negative effects of non-payment for services and because of the low level of consumer education, unscrupulous operators easily exploit ignorant communities (South Africa. Department of Housing, 1994:15, 50).

Education and training is the starting point that is needed to reach true development through housing in all four of its dimensions (Meyer et al, 1995:271). It has potential as a long-term strategy to promote 
learning opportunities to develop peoples' competence and confidence to become active participants in the development of their own communities (Kruger, 1993). It is important for housing development NGOs to include all four the pillars of sustainable housing development in their projects. Consumer Scientists who specialised in housing and adult education are ideally suited to assist NGOs in this regard.

\section{The NGO-sector}

NGOs have played, and are still playing, a significant role in the supplementing and building of capacity at community level (Harding, 1994:44; South Africa. Parliament, 1994:40), as well as in facilitating and promoting the housing development process in South Africa (Davies \& Madlavu, 1993:57). NGOs possess abundant knowledge, expertise and experience about the housing development process (Edwards \& Hulme, 1996:34; Meyer et al, 1995:39, 222; Ministry for the Public Service and Administration, 1995:67). Since most NGOs are small and flexible, they tend to be more creative and innovative in their development approaches (Bernstein, 1994:64). NGOs are ideally situated to educate and train communities because of their unique positioning at local level (Cross et al, 1995:74). The fact that NGOs are usually situated in or close to their target communities, gives them a comparative advantage over other development structures, e.g. the Government. They tend to have a more localised viewpoint of the needs of the community and a greater understanding of the issues that are relevant to the community (Edwards \& Hulme, 1996:107; Harding, 1994:4). The fact that they tend to have a greater emphasis on the community puts them in a more trusting relationship with the community and communities are therefore in some instances more willing to co-operate with NGOs than with the Government (Clark, 1991:47; Meyer et al, 1995:39). The NGOs furthermore have the freedom to work in politically volatile areas and thus reach the poor and disadvantaged the State cannot (Smillie \& Helmich, 1993:30)

\section{RESEARCH METHODOLOGY}

A two-step sampling process was used to identify the relevant respondents for the research. Because of the wide range and high turnover of NGOs in South Africa (Establishing a national development agency, 1997:2) and the lack of a relevant NGO database, many different sources were used to determine the universum for the research. These included:

- The Human Sciences Research Council's Prodder Newsletter (Volume 6, Issue 4, 1994), the Prodder directory of development organisations and the Prodder Internet site (http://www.web.co. za/cgi-bin/prodder/moreinfo).

- The Development Resources Centre's Nongovernment Organisations. South Africa. A Directory. 1998.

- The Urban Sector Network's Internet site (http:// www.sn.apc.org/usn/usn.html).

- The National Housing Forum Trust's Internet site (http://www.sn.apc.org/nhft).

- The NGO-Coalition.

- The Non-Governmental Organisations Review: Building for the people. Volume 1, May 1997.

- A list obtained from contact persons in the field.

The NGOs involved in housing development in South Africa were selected from the source documents through the use of relevant key words. A telephone survey was then conducted to establish the validity and relevance of these NGOs for the research (NGOs providing housing education and training). As part of the telephone survey, respondents were also asked if they had knowledge of any other NGOs that offer housing education and training. These names and contact numbers were then added to the sampling frame and contacted as well.

By using this method, forty NGOs were identified that provide housing education and training in South Africa. The housing education and training provided by them were classified into five categories, namely assistance and advice, building skills training, home decorating skills training, housing education and training on request only and structured housing education and training programmes. Since only eleven of the NGOs offered structured housing education and training programmes to communities, the whole of this universum was taken as respondents for the unstructured focused interviews. The dendrogram technique (Schutte, s.a.:4) was used to design the interview guide. The NGOs were asked about their purpose, missions, aims, functions, geographical areas of operation, target communities, the organisational structures and organisational processes. To ensure the reliability and validity of the measuring instrument, a pilot study was carried out, which included formal and informal testing of the interview guide. The principle researcher conducted all the interviews, which were recorded on audiocassettes and transcribed. This was an exploratory study and descriptive, qualitative data was obtained. The results of the interviews were reported in a descriptive report.

\section{RESULTS AND DISCUSSION}

\section{NGOs offering structured housing education and training programmes}

Only eleven NGOs in South Africa were found to offer structured housing education and training programmes as part of their housing development projects. They were:

- Afesis-Corplan

- Built Environment Support Group (BESG)

- Co-operative Housing Foundation

- Cope Housing Association

- Corporate Homes Trust

- Development Action Group (DAG)

- People's Dialogue

- Planact

- Small Projects Foundation

- Umzamo Development project

- Urban Services Group (USG) 
These NGOs will hereafter be referred to as 'housing education and training NGOs'. The housing education and training NGOs are concentrated in the urban areas of South Africa, and then specifically in the cities and towns of the Western and Eastern Cape, Gauteng and Kwazulu-Natal. Four of the organisations named Gauteng as a major area of operation, while five mentioned the Eastern Cape, three Natal and three the Western Cape. Only one NGO mentioned operating in Mpumalanga, the Free State and the North West Province, although their head office is located in Gauteng. Seven of the NGOs mentioned that they work exclusively in urban areas, while only three mentioned that they work in rural areas as well. There appears to be an uneven distribution of housing education and training NGOs in South Africa. There is a need for housing education and training NGOs to operate in all the provinces of South Africa, and in the rural areas as well.

\section{Housing functions performed by NGOs through their education and training programmes}

The purpose, missions and aims of the NGOs determine the functions of the NGOs and the services they render. Due to the broad context of housing and its close association with community development, the NGOs have more extensive functions than simply the physical development of housing stock. The main aim of all of the NGOs is to facilitate the development of housing stock and support community development. These aims materialise in different levels of functions and services. The basic functions that all the NGOs offer are the facilitation and support of housing development by equipping the community with knowledge and training them with the necessary skills to facilitate their participation in the housing process.

All of the NGOs go one step further in facilitating the physical building of housing stock. They are involved in the physical housing development or support to their target communities. Included as part of the services are technical advice and support, project management services, technical assistance through support centres, property management services, quantity surveying services, estate agency services, land acquisition facilitation and physical housing delivery. The NGOs in the study all disseminate knowledge to communities through housing education and training programmes, publications or support centres

A further function of nine of the NGOs is advocacy and housing policy development through involvement in policy development committees, advising different levels of government, training local government officials on various issues and facilitating forums for policy discussions between communities and the different stakeholders. This is an important function of the NGOs since the policy environment has a direct influence on the projects and the communities that they serve. One of the NGOs used to be involved in policy development through a provincial housing policy committee.

Nine of the NGOs in the research are involved in in- formation generation activities. These include research, the development of training materials, case studies of projects and the development of collective housing or participation models.

Six of the NGOs offer financial support services to communities in a variety of ways. These are in the form of bridging finance, micro loan finance, the formation and facilitation of savings schemes, as well as the administration of micro loan finance and funding/ subsidy applications.

Three of the NGOs offer internship programmes and exchange programmes that give communities a further chance to gain knowledge and develop skills through working in the NGOs or interacting with similar communities.

The broad functions of the NGOs are conceptualised in Figure 1.

The education and training programmes offered by the eleven NGOs can be divided into the three types shown in Table 1. Note should be taken of the fact that all 11 NGOs did adhere to the first pillar of development, namely the establishment of permanent physical residential structures with secure tenure. It is however not reported as the emphasis of the research was on housing education and training NGOs.

All the NGOs in the research include the second pillar of development in the education and training programmes to communities, which aims to disseminate knowledge and build community skills. Ten of the NGOs include the third pillar of development, which aims to build the capacity of community organisations, in training programmes. One NGO includes this pillar in its education and training programme for communities. Therefore all 11 NGOs comply to the third pillar of development as identified in this research. Only four of the NGOs include the fourth pillar of development that focuses on creating local employment opportunities for the community. In the following section, the different types of housing education and training programmes will be discussed in further detail.

\section{Housing education and training programmes for communities}

The first type of housing education and training programme focuses directly on the community and aims largely at equipping them with the necessary knowledge and skills to participate in the housing development process. All the NGOs in the research offer this type (Type 1 in Table 1 ) of housing education and training to their target communities, as well as to other interested parties.

Nine of the NGOs offer specific formal housing education and training courses, as well as non-formal training components throughout the project cycle. Two of the NGOs offer only non-formal, project-related training, although they cover the same components as the formal courses of the other NGOs. It is important for 


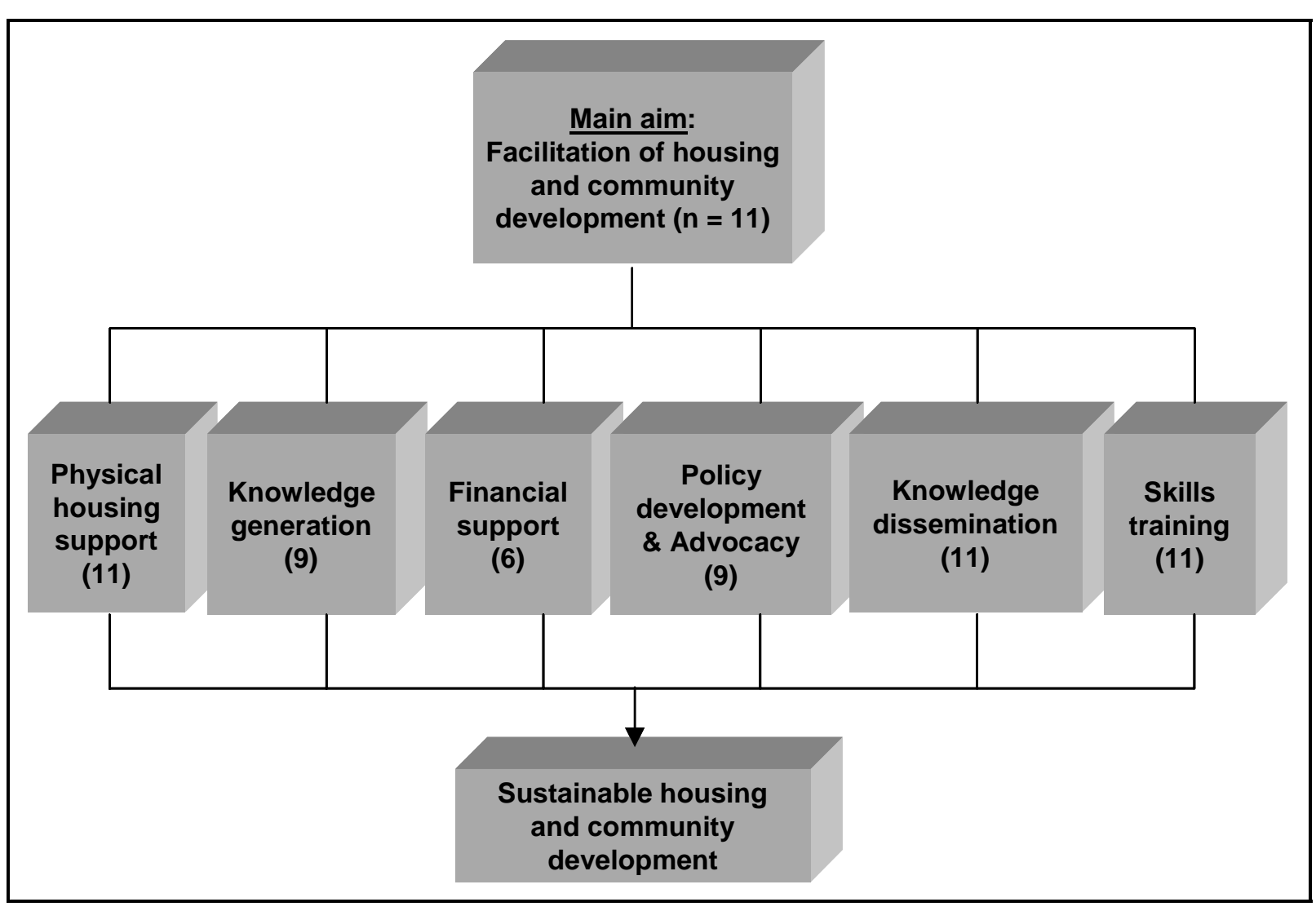

FIGURE 1: $\quad$ CONCEPTUALISATION OF THE FUNCTIONS OF THE NGOS

TABLE 1: TYPES OF HOUSING EDUCATION AND TRAINING PROGRAMMES

\begin{tabular}{|l|l|l|l|}
\hline $\begin{array}{c}\text { Housing education and } \\
\text { training programmes of- } \\
\text { fered by the NGOs to com- } \\
\text { munities }\end{array}$ & Basic aims of programmes & $\begin{array}{c}\text { Sustainable housing } \\
\text { development pillars } \\
\text { included in pro- } \\
\text { grammes }\end{array}$ & $\begin{array}{c}\text { Number of NGOs } \\
\text { offering pro- } \\
\text { grammes }\end{array}$ \\
\hline $\begin{array}{l}\text { 1. } \\
\begin{array}{l}\text { Housing education and } \\
\text { training for communities. }\end{array}\end{array}$ & $\begin{array}{l}\text { Knowledge and basic skills to en- } \\
\text { able communities to participate in } \\
\text { housing development process }\end{array}$ & Pillar 2 & All 11 \\
\hline 2. $\begin{array}{l}\text { Housing education and } \\
\text { training for community- } \\
\text { based organisations } \\
\text { (CBOs). }\end{array}$ & Organisational development & Pillars 2 \& 3 & $\begin{array}{l}11 \\
\text { (One NGO includes it } \\
\text { in its programme for } \\
\text { communities) }\end{array}$ \\
\hline 3. $\begin{array}{l}\text { Housing education and } \\
\text { training for community } \\
\text { housing advisors. }\end{array}$ & $\begin{array}{l}\text { Housing issues, builds capacity to } \\
\text { run housing organisations, man- } \\
\text { age the housing process and cre- } \\
\text { ating local employment opportuni- } \\
\text { ties }\end{array}$ & $\begin{array}{l}\text { Pillars } 2 \& 3 \\
\& 4\end{array}$ & 4 \\
\hline
\end{tabular}

* All 11 NGOs offer the first pillar of housingdevelopment

the communities to learn certain facts, for instance on the subsidy system, but in order for the capacity of the community to be built, the facts need to be drawn through to the day-to-day running of the project. It would thus appear that the ideal situation would be a balance between formal housing education and training courses and informal project-related learning, through physical involvement in the running and management of the project.
As can be seen in Figure 2, all the NGOs (11) include sections on housing finance, the housing process and housing policy in their courses, while most (10) also include a section on the development process. Nine (9) of the NGOs include technical skills and eight (8) consumer education in their programmes. Five (5) of the NGOs include a section on institution building, while urban development and organisational processes are each included in the programmes of one NGO. 


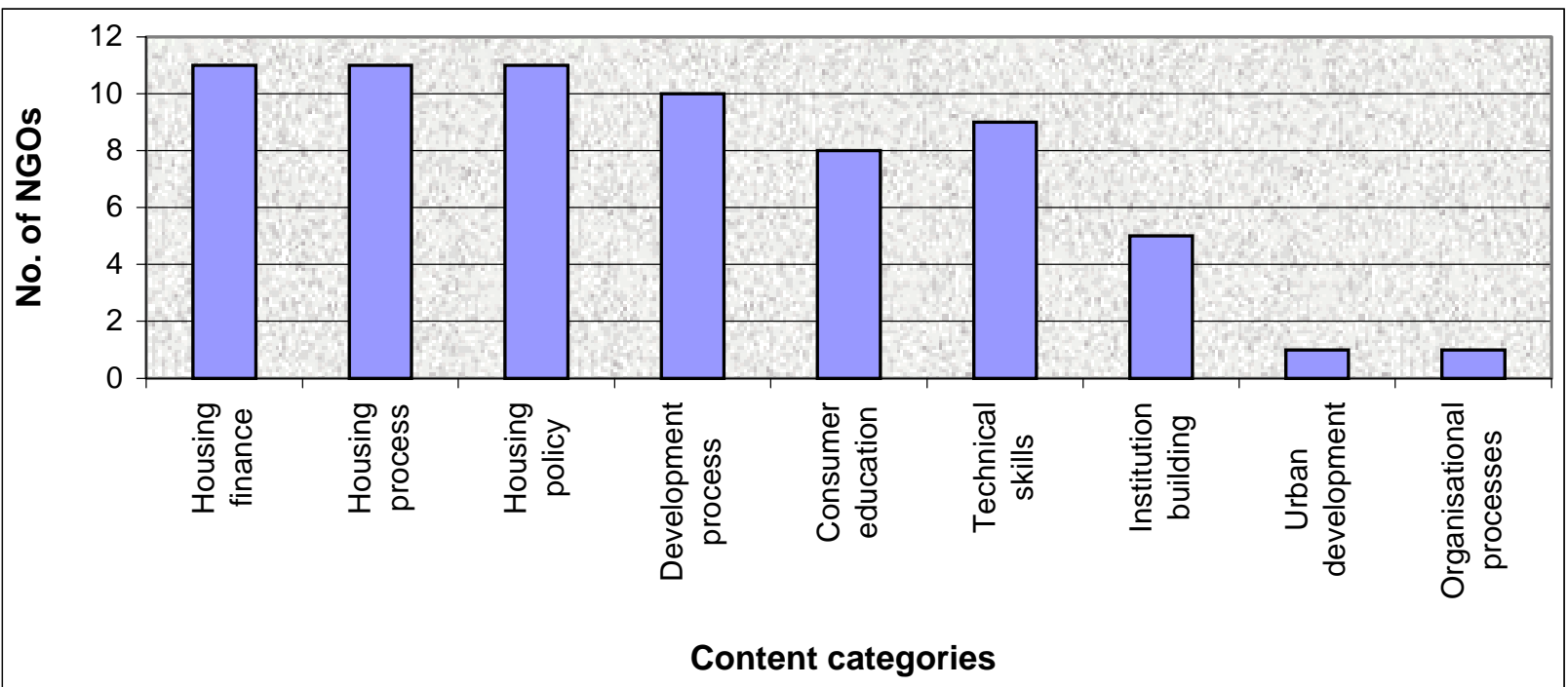

FIGURE 2: ASPECTS COVERED IN THE HOUSING EDUCATION AND TRAINING PROGRAMMES OFFERED TO COMMUNITIES BY THE NGOS

All of these programmes cover the basic knowledge and skills that a community needs to enable them to participate in the housing development process, while some include additional facts and skills as well. They all cover the second pillar of sustainable housing development by equipping communities with the necessary knowledge and skills to participate in their own development.

\section{Housing education and training programmes for community-based organisations}

The second type of education and training is aimed at creating the necessary capacity to guide the housing development process and ensure the sustainability of the projects (Figure 3 ). It is mostly based on setting up and building the capacity of community-based organisations. Organisational education and training programmes (Type 2 in Table 1 ) are offered by ten (10) of the NGOs in the research. Most (7) of these have specific formal organisational education and training courses that are offered to the communitybased organisations or committees, while three offer this type of training non-formally as part of their project cycles. The NGO that does not offer a separate organisational education and training programme does include certain organisational processes in its housing education and training programme for communities (Type 1 in Table 1).

The ten NGOs that offer organisational education and training programmes cover a wide variety of concepts as well as training initiatives in their programmes. All ten (10) of the NGOs cover the housing process, housing technical skills, housing policy, organisational processes, organisational management skills, communications management and financial administration in their programmes. Nine (9) of the NGOs offer a section on the project development process and five (5) on community development as a part of their pro- gramme. Training on legal matters is included by three of the NGOs, while one also includes consumer education and business education.

All the organisational education and training programmes are aimed at building the capacity of the communities to set up and run community-based organisations that can manage and sustain the housing development process. These ten NGOs therefore include the third pillar of sustainable housing development in their housing education and training programmes, namely the strengthening of communitybased organisations, as the vehicles that are best positioned to drive and sustain development in communities.

\section{Housing education and training for community housing advisors}

Four (4) of the NGOs offer housing education and training programmes for community-based housing advisors (Type 3 in Table 1). This third type of housing education and training is aimed at creating longterm sustainability in the communities by building the capacity of community members to the level of paraprofessionals, by creating job opportunities for them, as well as equipping them to train other communities in turn. All these courses offered by the four NGOs aim to empower community members to support their communities in housing and organisational development issues and to create employment opportunities for the participants.

All four NGOs include sections on the housing process, technical housing skills, construction management, housing finance, organisational processes, the housing policy, legal matters, administration and business skills. Three (3) of the NGOs cover aspects of the project development process, while one includes health and safety in the workplace (Figure 4). 


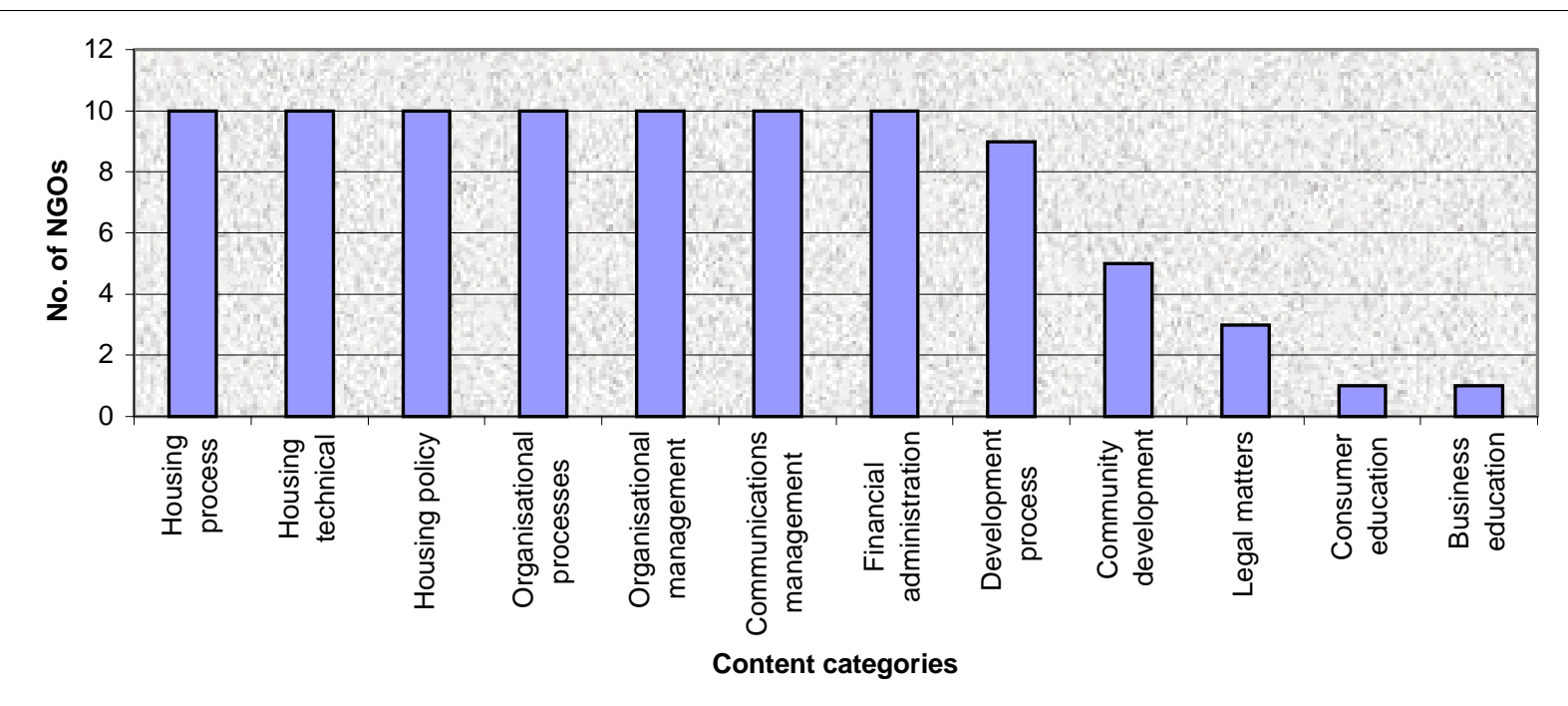

FIGURE 3: $\quad$ ASPECTS COVERED IN THE ORGANISATIONAL DEVELOPMENT PROGRAMMES

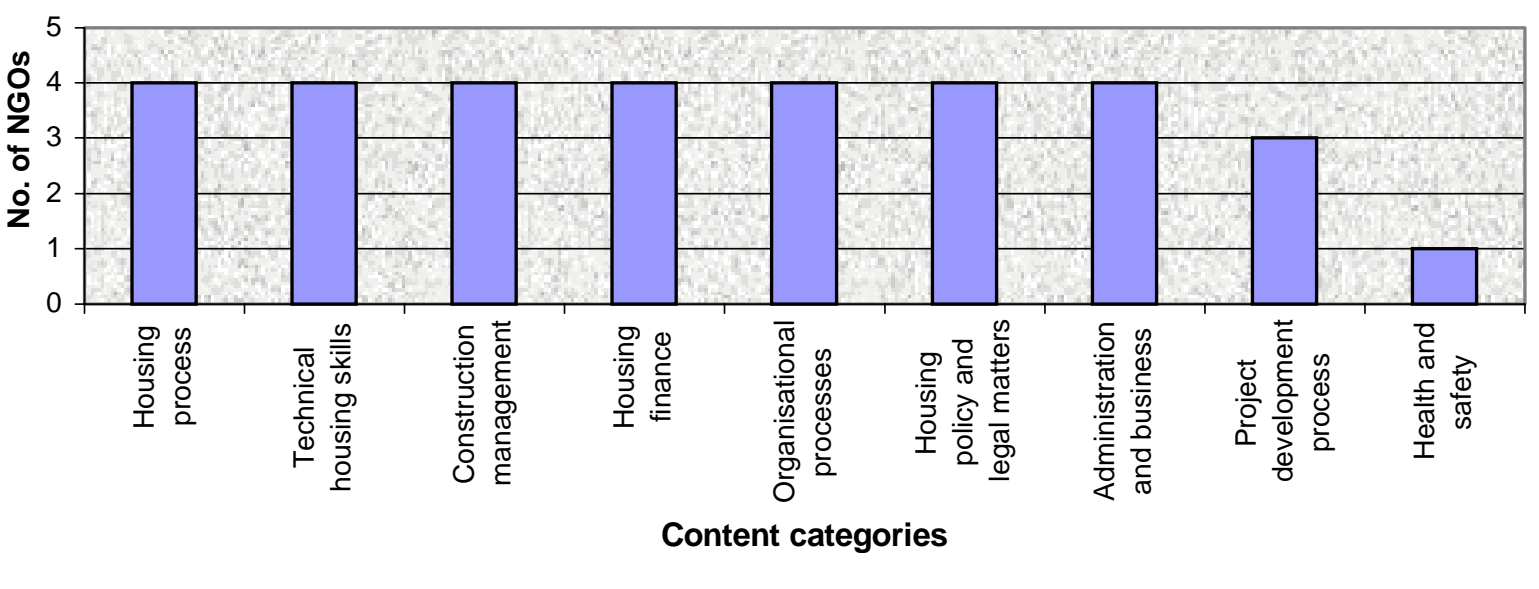

FIGURE 4: ASPECTS COVERED IN THE NGO-PROGRAMMES FOR COMMUNITY HOUSING ADVISORS

One NGO offers a course with four levels. The first level trains housing advisors to provide technical advice to individual households. The second level qualifies the participants to be facilitators who can offer advice to mutual building programmes. The third level prepares the participants to be emerging contractors, while the fourth level equips participants with the necessary skills to be community liaison officers within their communities. This course is accredited with a university certificate and designed in terms of the NQF requirements.

These four courses are more skills-orientated than the other two types of housing education and training courses. They not only train the communities on housing issues and build their capacity to run housing organisations, but they also train community members to go out and manage the housing process up to a certain level. These courses have a greater focus on business, financial and technical housing skills, which the participants can use to create jobs for themselves within their communities. These NGOs therefore include the fourth pillar of sustainable housing development in their projects by also focusing on job creation within the community.

\section{CONCLUSIONS AND RECOMMENDATIONS}

Due to the fact that only eleven NGOs in South Africa were found to offer structured housing education and training programmes, a definite need exists for the establishment of more housing education and training NGOs throughout South Africa in provinces such as the Northern Province and the Northern Cape in particular. The areas of operation of the existing housing education and training NGOs also need to be extended to include the rural areas of all nine provinces. 
It is encouraging to see that all of the housing education and training NGOs realise that sustainable housing development is dependent on more than one pillar of development and should therefore include both capacity building (at community and community-based organisation level) and physical housing development in their projects.

All the NGOs aim to build the capacity of their communities and facilitate physical housing developments, but only four of them include the fourth pillar of sustainable housing development, namely, local economic development through teaching the communities how to utilise their skills in creating income for themselves. The NGOs should therefore focus more strongly on the fourth pillar of sustainable housing development. Income-generating activities, entrepreneurship training and small business training should be included in projects to enable communities to become economically sustainable (Table 2 ).

In-depth evaluations should be done of specific housing development projects in order to establish the long-term benefits of the inclusion of the four pillars of sustainable development in housing development projects.

The housing education and training courses offered by the NGO-sector should be standardised and accredited into the broader National Qualifications Framework (NQF). This would offer communities long-term career path opportunities and create further opportunities for economic development. There is, therefore, a need for an in-depth study into the quality and long-term benefits of housing education and training offered by the NGO-sector in South Africa.

\section{CONCLUDING REMARKS}

The field of housing education and training is a new challenge in the spectrum of South African education that needs to be addressed. Consumer Scientists are ideally suited to work in the housing education and training sector, due to their multi-disciplinary, holistic view achieved through the integration of knowledge and skills of adult education, community development and housing issues. It is therefore imperative that Consumer Scientists and related disciplines accept this challenge by including more housing education and training concepts in their learning programmes and by seeking solutions to the problems in this field.

Many NGOs work in fields that are related to Consumer Science, such as housing, community develop-

\section{TABLE 2: INCLUSION OF THE PILLARS OF SUS- TAINABLE DEVELOPMENT IN THE HOUSING PROJECTS OF THE NGOS}

\begin{tabular}{|c|c|}
\hline $\begin{array}{c}\text { NGOs including all 4 } \\
\text { pillars in their housing } \\
\text { projects }\end{array}$ & $\begin{array}{c}\text { NGOs including the first } \\
\mathbf{3} \text { pillars in their housing } \\
\text { projects }\end{array}$ \\
\hline 4 & 11 \\
\hline
\end{tabular}

ment, adult education, empowerment, gender equality and nutrition. Consumer Science at tertiary institutions and NGOs could mutually benefit from linking with each other and working together. Students placed at NGOs for practical experience would gain knowledge and skills pertaining to research, community development, housing education and training programmes and housing projects. The NGOs, that are usually understaffed, would have assistants to help alleviate their workload. The tertiary institutions could furthermore use the feedback from the students' experiences to adapt their curricula to make it more relevant, thereby offering better qualified staff to the future job market.

NGOs and Consumer Scientists could widen their scope of knowledge and experience by forming working relationships, thus coming closer to the vision that they all share, namely the improvement of quality of life.

\section{REFERENCES}

Bernstein, A. 1994. NGOs and a democratic South Africa in development and democracy. Johannesburg. Urban Foundation.

BOEREN, A. 1992. Getting involved: Communication for participatory development. Community Development Journal 27(3):259-271.

CERNEA, M. 1992. The building blocks of participation: Testing bottom-up planning. Washington D.C. The World Bank

CLARK, J. 1991. Democratizing development. The role of voluntary organizations. West Hertford. Kumarian.

CROSS, C, CLARK, C. \& BEKKER, S. 1995. Coming clean. Creating transparency in development funding in South Africa. Durban. Indicator Press.

DAVIES, B \& MADLAVU, M. 1993. Community-based development organisations in the Eastern Cape: Towards survival and sustainability. Grahamstown: Development studies Working Paper No. 59. Rhodes University.

EDWARDS, M \& HULME, D. 1996. Non-Governmental Organisations - Performance and accountability. United Kingdom. Earthscan

Establishing a national development agency. 1997. NGO Review 1:2-3.

FOWLER, A. 1994. Development, democratization, and NGOs in development and democracy. Johannesburg. Urban Foundation.

FRANKS, TR. 1996. Managing sustainable development: definitions, paradigms, and dimensions. Sustainable Development 4(2):53-60.

GOW, DD \& MORSS, ER. 1988. The notorious nine: Critical problems in project implementation. World Development 16 (12):1399-1988.

HARDING, D. 1994. From global to local: Issues and challenges facing NGOs. Olive Information Service. Avocado series.

JEPPE, WJO. 1985. Community development: An African rural approach. Pretoria. Africa Institute of South Africa.

JEPPE, WJO. 1992. Die ontwikkelingsrol van Nie-Regerings Organisasies (NGOs). Departement Ontwikkelingsadministrasie. Universiteit Stellenbosch. Stellenbosch.

KRUGER, A. 1993. Local communities and urban regeneration: The contribution of community education. Community Development Journal 28(4):342-354.

MEYER, IH, THERON, F \& VAN ROOYEN, A. (eds). 1995.

Public and development management. Bellville. School of 
Public Management. University of Stellenbosch. Stellenbosch.

MIKKELSON, B. 1994. Methods for development work and research. Newbury Park. Sage.

SCHUTTE, D. s.a. Notes on the dendrogram technique for the development of questionnaires. UNISEARCH research consultancy. Strand.

SMILLIE, I \& HELMICH, H. (eds). 1993. Non-governmental organisations and Governments: Stakeholders for development. Paris. Organisations for Economic Co-operation and Development

South Africa. Department of Housing. 1994. White paper on
Housing: A new housing policy and strategy for South Africa. Pretoria. Government Printer.

South Africa. Department of Housing. 1997a. Housing Act. Act 107 of 1997. Pretoria. Government Printer.

South Africa. Department of Housing. 1997b. Housing the nation: doing justice to delivery. A report prepared by the Minister of Housing. Pretoria. Government Printer.

South Africa. Ministry for the public service and administration 1995. White paper on the transformation of the public service. Pretoria. Government Printer.

South Africa. Parliament. 1994. White Paper on Reconstruction and Development. Cape Town. Government Printer. 